\begin{tabular}{l} 
Sharif University of Technology \\
Scientia Iranica \\
SCIENTIA \\
IRANICA \\
Transtions A: Civil Engineering \\
\hline
\end{tabular}

\title{
Fundamental period of vibration for seismic design of concrete shear wall buildings
}

\author{
A. Badkoubeh and A. Massumi* \\ Department of Civil Engineering, Faculty of Engineering, Kharazmi University, No. 43, Dr. Mofatteh Ave., Tehran, P.O. Box \\ 15719-14911, Iran.
}

Received 8 December 2015; received in revised form 19 January 2016; accepted 13 February 2016

\section{KEYWORDS \\ Fundamental period; \\ Concrete shear wall \\ buildings; \\ Code periods; \\ Closed-form solution; \\ Lower bound period.}

\begin{abstract}
A simple expression is proposed to estimate the fundamental period of vibration for concrete Shear Wall (SW) buildings. Most seismic codes specify empirical period formulas for seismic design. In this study, fundamental period data for concrete SW buildings recorded during California earthquakes between 1971 and 1994 were compared with the current US code formulas. It is shown that these formulas are inadequate for estimation of the fundamental period of concrete SW buildings. A closed-form period solution based on Rayleigh's method using SW displacement as a parameter is proposed to estimate the fundamental period of concrete SW buildings in low, moderate, and high seismicity regions. The accuracy of the closed-form solution is verified using recorded periods, and it confirms that the proposed expression provides reasonable estimates of the lower bound of a period. The results show that the fundamental period of concrete SW buildings depends significantly on the displacement and mechanical properties of the SW.
\end{abstract}

(C) 2017 Sharif University of Technology. All rights reserved.

\section{Introduction}

An empirical formula is proposed to estimate seismic base shear and lateral seismic loads for building codes. Typically, seismic design loads vary with the fundamental period of a structure; a simple empirical expression dependent on building geometry is presented to calculate this period. The formula is useful for the design of structures because the fundamental period is not known before the first trial design. A seismic load usually decreases as the period increases; formulas provide a lower estimation of a period so that the seismic load is not underestimated.

There are limited data on the response of concrete Shear Wall (SW) buildings and steel-braced frames

* Corresponding author. Tel.: +98 2188830891 ; Fax: +982188329213

Email addresses: alireza.badkoubeh@studio.unibo.it (A.

Badkoubeh); massumi@khu.ac.ir (A. Massumi) during earthquakes. These systems came into common use after the Northridge and Kobe earthquakes, and the empirical period formulas were developed with similar data, but without extensive validation [1]. For instance, in ATC3-06 [2] and earlier US building codes, the following equation was proposed for the design period of concrete SW buildings:

$$
T_{a, \mathrm{ATC}}=0.09 \frac{h_{n}}{\sqrt{D_{s}}},
$$

where $h_{n}$ and $D_{s}(\mathrm{~m})$ are, respectively, building height and the SW dimension in the direction parallel to the seismic forces. Eq. (1) is presented in the National Building Code of Canada (NBCC) [3] for the design period of steel-braced frames in which $D_{s}$ is the width of the braced frame.

Similarly, in ASCE SEI/7-10 [4], the design period of structures is given by:

$$
T_{a, \mathrm{ASCE}}=C_{T} h_{n}^{x}
$$


where $h_{n}(\mathrm{~m}), C_{T}=0.0488$, and $x=0.75$ are applied to concrete SW buildings and concentrically steelbraced frames. In this expression, the fundamental period of the building varies only with the building height. Where the SW width varies in building height, or where there are several bays in a SW, the use of $D_{s}$ creates design problems.

Housner and Brady [5] stated that Eq. (1) poorly fits measured periods and that the use of $D_{s}$ in period formulas is less accurate than the simple expression where $T$ varies linearly with building height. Methods, such as those by Cole et al. [6] and Li and Mau [7], have demonstrated that code period formulas are inadequate for concrete SW buildings.

Goel and Chopra [8] proved that Eq. (1) correlates poorly with the measured periods for concrete SW buildings from the California earthquakes. They also showed that the use of Eq. (2) for the fundamental period of a building underestimates seismic forces. They developed a refined expression with additional geometric parameters, such as depth and wall area.

Lee et al. [9] concluded that the period formulas in building codes such as NBCC [3] and UBC [10] are not sufficient to estimate the fundamental period of apartment buildings with shear wall dominant systems. They proposed an improved formula by regression analysis based on the measured period data.

Ghirb and Mamedov [11] investigated the effect of base flexibility on SW building periods, and also found that the code period formulas were inadequate. Kown and Kim [12] compared the code formulas and records of periods for several buildings during earthquake events, and found that the period formulas for seismic design codes for concrete SW buildings were relatively high. They stated that the formula for buildings with shear walls considerably overestimated the periods at all building heights.

Barghi and Azadbakht [13] showed that the infill effects on fundamental periods of steel momentresisting frames are highly considerable and proposed a new formula by finite element analysis. Kuşylmaz and Topkaya [14] also used Rayleigh's method as a basis and roof drift ratio under seismic forces as a parameter to estimate the fundamental period of vibration of building structures in general and steel Eccentrically Braced Frames (EBFs) in particular. They revealed that the building displacement in period formula offers closer estimates.

Although the value of $C_{T}$ correlates poorly with recorded periods for concrete SW buildings [1], Eq. (2) is still recommended in the current US building codes such as NEHRP [15], UBC [10], and IBC [16]. Eq. (2) is also used in Euro Code 8 [17] for up to $40 \mathrm{~m}$ in height for analysis of equivalent lateral force. In ASCE SEI/710 [4], $C_{T}=0.0724$ and $x=0.8$ are recommended for steel moment-resisting frames, $C_{T}=0.0466$ and $x=$
0.9 for concrete moment-resisting frames, and $C_{T}=$ 0.0488 and $x=0.75$ for all other structural systems, including concrete SW and steel-braced frames.

In this study, a database is presented for measured fundamental periods for concrete SW buildings (denoted as "measured periods") from 9 California earthquakes between 1971 and 1994. The measured periods are compared with code period formulas for concrete SW buildings. The results show that the geometric and mechanical properties of SWs are very effective for periods, and that code formulas using only the height of the building do not show good validation for period estimation. A simple expression based on Rayleigh's method using SW height as a parameter is proposed for period estimation. Comparing the measured periods and the refined expression confirms that the proposed simple expression provides a reasonable lower bound for a period for concrete SW buildings in low, moderate, and high seismicity regions.

\section{Period database}

The fundamental periods of concrete SW buildings have been recorded during several California earthquakes. This database includes 106 buildings, 21 of which have experienced peak ground accelerations greater than $0.15 \mathrm{~g}\left(\ddot{u}_{g} \geq 0.15 \mathrm{~g}\right)$ in the 1994 Northridge earthquake. The remaining data come from the response of buildings recorded during the 1971 San Fernando, 1979 Lytle Creek, 1984 Morgan Hill, 1986 Mt. Lewis and Palm Spring, 1987 Whittier, 1989 Loma Prieta, 1990 Upland, and 1991 Sierra Madre earthquakes [6,18-25]. Table 1 shows a subset of this database containing 16 concrete SW buildings (27 records) [8].

\section{Empirical formulas in building codes}

Figure 1 compares Eqs. (1) and (2) for concrete SW buildings with typical values for $h_{n}$ and $D_{s}$. For the whole range of values, $T_{a, \mathrm{ASCE}}$ is shorter than $T_{a, \mathrm{ATC}}$ and this difference increases as building height increases. In ASCE SEI/7-10 [4], the periods obtained from methods, such as Rayleigh's method and eigenvalue analysis, can be used, provided that they are not larger than $C_{u} T_{a} . C_{u}$ varies from 1.4 in high seismicity regions to 1.7 in low seismicity regions. The values for $C_{u}$ greater than 1.4 can be justified by eigenvalue analysis. In the use of this approach where $T_{a}$ is multiplied by $C_{u}$, the value for $T_{a, \mathrm{ASCE}}$ is closer to that for $T_{a, \mathrm{ATC}}$.

Figure 2 compares the measured periods and those from Eqs. (1) and (2) versus $h_{n}$ for buildings listed in Table 1. For a majority of buildings, these code formulas provide periods that are longer than the measured periods, which lead to smaller values for the 
Table 1. Period data for concrete SW buildings [8].

\begin{tabular}{|c|c|c|c|c|c|c|c|c|c|c|c|}
\hline \multirow[t]{2}{*}{$\begin{array}{l}\text { Building } \\
\text { number }\end{array}$} & \multirow[t]{2}{*}{ Location } & \multirow[t]{2}{*}{$\begin{array}{c}\text { ID } \\
\text { number }\end{array}$} & \multirow[t]{2}{*}{$\begin{array}{c}\text { Number } \\
\text { of } \\
\text { stories }\end{array}$} & \multirow[t]{2}{*}{$\begin{array}{c}\text { Height } \\
(\mathrm{m})\end{array}$} & \multirow[t]{2}{*}{ Earthquake } & \multicolumn{2}{|c|}{$\begin{array}{c}\text { PGA } \\
(\mathrm{g})\end{array}$} & \multicolumn{2}{|c|}{$\begin{array}{c}\text { Period } \\
(\text { sec })\end{array}$} & \multirow[t]{2}{*}{$\begin{array}{c}\text { Width } \\
(\mathbf{m})\end{array}$} & \multirow[t]{2}{*}{$\begin{array}{c}\text { Length } \\
\text { (m) }\end{array}$} \\
\hline & & & & & & Longitud & ansverse & Longitud & ansverse & & \\
\hline 1 & Belmont & C58262 & 2 & 8.5 & Loma Prieta & 0.10 & 0.11 & 0.13 & 0.20 & NA & NA \\
\hline $2^{*}$ & Burbank & $\mathrm{C} 24385$ & 10 & 26.8 & Northridge & 0.26 & 0.30 & 0.60 & 0.56 & 22.9 & 65.6 \\
\hline $3^{*}$ & Burbank & C24385 & 10 & 26.8 & Whittier & 0.22 & 0.26 & 0.57 & 0.51 & 22.9 & 65.6 \\
\hline 4 & Hayward & C54488 & 4 & 15.2 & Loma Prieta & 0.05 & 0.04 & 0.15 & 0.22 & NA & NA \\
\hline 5 & Long Beach & C14311 & 5 & 21.6 & Whittier & 0.10 & 0.10 & 0.17 & 0.34 & 24.7 & 65.6 \\
\hline 6 & Los Angeles & ATC 3 & 12 & 48.5 & San Fernando & NA & NA & 1.15 & MRF & 18.3 & 49.1 \\
\hline $7^{*}$ & Los Angeles & $\mathrm{C} 24468$ & 8 & 38.7 & Northridge & 0.16 & 0.11 & 1.54 & 1.62 & 19.2 & 47.0 \\
\hline $8^{*}$ & Los Angeles & $\mathrm{C} 24601$ & 17 & 45.7 & Northridge & 0.26 & 0.19 & 1.18 & 1.05 & 24.4 & 69.2 \\
\hline 9 & Los Angeles & C24601 & 17 & 45.7 & Sierra Madre & 0.07 & 0.06 & 1.00 & 1.00 & 24.4 & 69.2 \\
\hline $10^{*}$ & Los Angeles & N253-5 & 12 & 49.2 & San Fernando & 0.26 & 0.19 & 1.19 & 1.14 & 23.2 & 47.6 \\
\hline $11^{*}$ & Los Angeles & N253-5 & 12 & 49.2 & San Fernando & 0.26 & 0.19 & 1.07 & 1.13 & 23.2 & 47.6 \\
\hline 12 & Palm Desert & C12284 & 4 & 15.3 & Palm Spring & 0.07 & 0.12 & 0.50 & 0.60 & 18.3 & 54.9 \\
\hline 13 & Pasadena & N264-5 & 10 & 43.3 & Lytle Creek & 0.02 & 0.02 & 0.71 & 0.52 & 21.0 & 22.9 \\
\hline $14^{*}$ & Pasadena & N264-5 & 10 & 43.3 & San Fernando & 0.18 & 0.22 & 0.98 & 0.62 & 21.0 & 22.9 \\
\hline $15^{*}$ & Pasadena & N264-5 & 10 & 43.3 & San Fernando & 0.18 & 0.22 & 0.97 & 0.62 & 21.0 & 22.9 \\
\hline 16 & Piedmont & C58334 & 3 & 11.0 & San Fernando & 0.08 & 0.07 & 0.18 & 0.18 & $\mathrm{NA}$ & NA \\
\hline 17 & Pleasant Hill & C58348 & 3 & 12.4 & San Fernando & 0.08 & 0.13 & 0.38 & 0.46 & 23.5 & 40.0 \\
\hline 18 & San Bruno & C58394 & 9 & 31.7 & San Fernando & 0.11 & 0.13 & 1.20 & 1.30 & 25.6 & 58.6 \\
\hline 19 & San Bruno & C58394 & 9 & 31.7 & San Fernando & 0.11 & 0.13 & 1.00 & 1.45 & 25.6 & 58.6 \\
\hline 20 & San Jose & C57355 & 10 & 37.8 & San Fernando & 0.09 & 0.11 & MRF & 0.75 & 25.0 & 58.0 \\
\hline 21 & San Jose & C57355 & 10 & 37.8 & Morgan Hill & 0.06 & 0.06 & MRF & 0.61 & 25.0 & 58.0 \\
\hline 22 & San Jose & C57355 & 10 & 37.8 & Mount Lewis & 0.03 & 0.03 & MRF & 0.61 & 25.0 & 58.0 \\
\hline 23 & San Jose & C57356 & 10 & 29.3 & Loma Prieta & 0.10 & 0.13 & 0.73 & 0.43 & 19.5 & 64.1 \\
\hline 24 & San Jose & C57356 & 10 & 29.3 & Loma Prieta & 0.10 & 0.13 & 0.70 & 0.42 & 19.5 & 64.1 \\
\hline 25 & San Jose & C57356 & 10 & 29.3 & Morgan Hill & 0.06 & 0.06 & 0.65 & 0.43 & 19.5 & 64.1 \\
\hline 26 & San Jose & C57356 & 10 & 29.3 & Mount Lewis & 0.04 & 0.04 & 0.63 & 0.41 & 19.5 & 64.1 \\
\hline $27^{*}$ & Watsonville & $\mathrm{C} 47459$ & 4 & 20.2 & Loma Prieta & 0.39 & 0.28 & 0.24 & 0.35 & 21.7 & 22.9 \\
\hline
\end{tabular}

*: Building with $\ddot{u}_{g} \geq 0.15 \mathrm{~g}$; number followed by "C" or "N": Station number;

number followed by "ATC": Building number in ATC3-06 report (NBS 1978); NA: Data Not Available;

MRF: Moment-Resisting Frame.

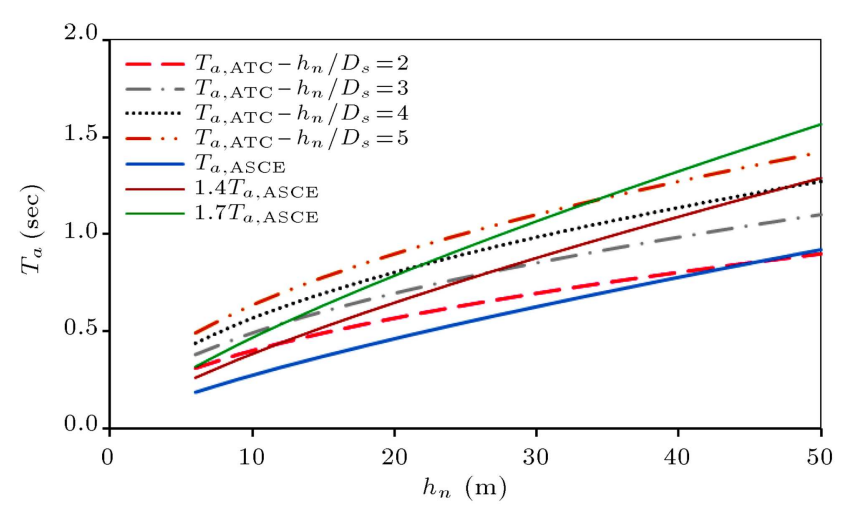

Figure 1. Comparison of period formulas in 2010 ASCE and 1978 ATC for concrete SW buildings.

seismic design coefficients. If the code period is larger than the measured period and falls outside the flat portion of the design response spectrum, the seismic design forces will be underestimated. In this case, the values for $1.4 T_{a}$ and $1.7 T_{a}$ in the code buildings may be inappropriate.

Figure 3 shows the design spectral response ac- celeration from $T_{a, \mathrm{ASCE}}$ and measured periods against $h_{n}$ for buildings listed in Table 1 (Site Class D). As shown in the figure, the spectral response acceleration from measured periods for some buildings is larger than the spectral response acceleration from $T_{a, \mathrm{ASCE}}$. This indicates that considering solely building height in the period of a concrete SW building may provide inaccurate estimations, because the measured periods of some buildings with similar heights can be totally different.

In Table 1, buildings 4 and 12 have heights of $15.2 \mathrm{~m}$ and $15.3 \mathrm{~m}$ and longitudinal periods of $0.15 \mathrm{sec}$ and $0.5 \mathrm{sec}$, respectively. Although these two buildings are equal in height, the period of building 12 is three times larger than that of building 4 . In addition, the measured longitudinal periods of buildings 2 and 10 are both $0.26 \mathrm{sec}$, but their respective heights are $26.8 \mathrm{~m}$ and $49.2 \mathrm{~m}$. Figure 2(a) shows that using $D_{s}$ alone is no more advantageous than using $h_{n}$ alone in a period formula. A more refined expression is required that considers SW height and geometry to estimate the fundamental period of concrete SW buildings. 


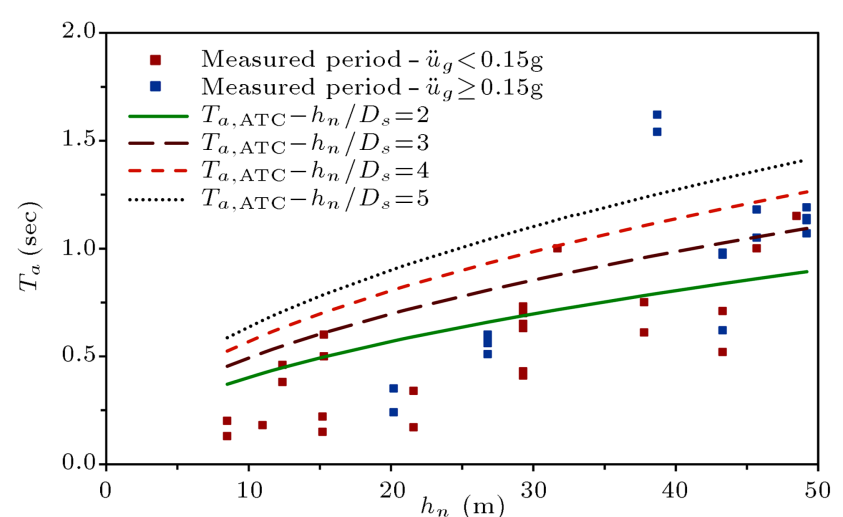

(a)

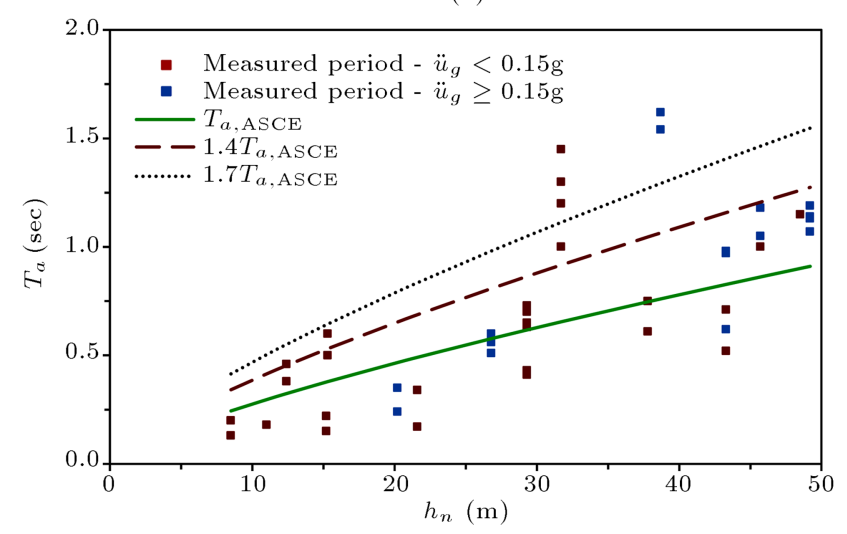

(b)

Figure 2. Comparison of (a) $T_{a, \mathrm{ATC}}$, (b) $T_{a, \mathrm{ASCE}}$, and measured periods for concrete SW buildings.

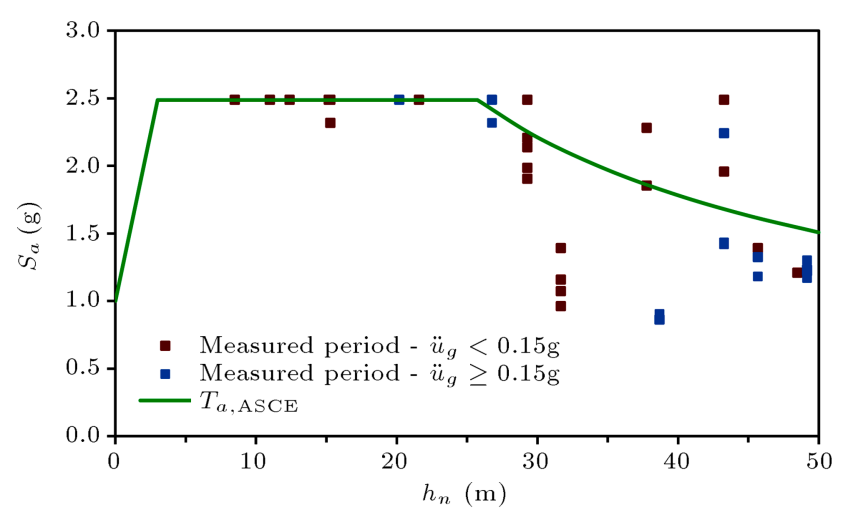

Figure 3. Comparison of 2010 ASCE spectral response acceleration from $T_{a, \mathrm{ASCE}}$ and measured periods for concrete SW buildings (Site Class D).

\section{Closed-form solution for period estimation}

A continuous cantilevered shear-beam model with distributed mass is considered as the structural system for a concrete SW building. The period of this model using Rayleigh's method is:

$$
T=2 \pi \sqrt{\int_{0}^{h_{n}} m(x) \cdot[u(x)]^{2} d x / \int_{0}^{h_{n}} f(x) \cdot u(x) d x}
$$

where $m(x)$ is the mass, $u(x)$ is the lateral deformation, $f(x)$ is the lateral force, $h_{n}$ is the building height, and $x$ is the vertical coordinate from the base.

For simplicity, the mass of the model is considered to be uniform as in the following:

$$
m(x)=\frac{W}{g \cdot h_{n}},
$$

where $W$ is the effective seismic weight and $g$ is the ground acceleration. The lateral force is assumed to increase linearly over the building height:

$$
f(x)=\frac{2 V \cdot x}{h_{n}^{2}},
$$

where $V$ is the seismic base shear. For simplicity, the concentrated load at the top of the building $\left(F_{t}\right)$ is ignored. ASCE SEI/7-10 [4] considers the seismic base shear to be:

$$
V=C_{s} \cdot W
$$

where $C_{s}$ is the seismic response coefficient, and $W$ is the effective seismic weight. $C_{s}$ is:

$$
C_{s}=\frac{S_{a}}{\left(\frac{R}{I_{e}}\right)}
$$

in which $S_{a}$ is the design spectral response acceleration, $R$ is the response modification coefficient, and $I_{e}$ is the importance factor of the structure.

As shown in Figure 4, to estimate the lateral deformation, $u(x)$ is considered as:

$$
u(x)=\psi(x) . \delta_{u},
$$

where $\psi(x)$ is a shape function, and coefficient $\delta_{u}$ is the maximum deformation of the wall. For a SW such as a

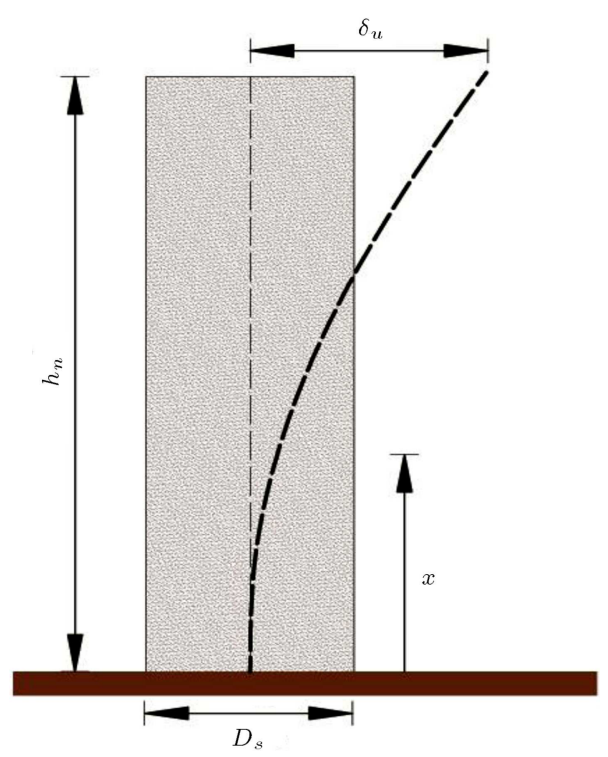

Figure 4. Lateral deformation of the wall. 
cantilevered beam, a shape function can be considered as:

$$
\psi(x)=1-\cos \left(\frac{\pi x}{2 h_{n}}\right) .
$$

For coefficient $\delta_{u}$, the design displacement of the wall is considered as developed by Wallace [26]:

$$
\delta_{u}=Z \cdot h_{n},
$$

where $Z$ is:

$$
\begin{aligned}
Z= & \left\{\varepsilon_{c u}\left(\alpha \frac{t_{w}}{l_{w}} \frac{l_{w}}{c}\right)\left(1-\frac{\alpha}{2} \frac{t_{w}}{h_{w}}\right)\right. \\
& \left.+\frac{\varepsilon_{s y}}{1-c / l_{w}}\left(\frac{11}{40} \frac{h_{w}}{l_{w}}-\alpha \frac{t_{w}}{l_{w}}+\alpha^{2} \frac{t_{w}}{h_{w}} \frac{t_{w}}{l_{w}}\right)\right\},
\end{aligned}
$$

where $\varepsilon_{c u}$ denotes the ultimate concrete compressive strain of $0.003, \varepsilon_{s y}$ is the tensile reinforcement yield strain, and $t_{w}, l_{w}$, and $h_{w}$ are the thickness, length, and height of the wall, respectively. Parameter $\alpha$ is obtained from $l_{p}=\alpha l_{w}$, where $l_{p}$ is the plastic hinge length, and $c$ is the neutral axis depth for the nominal moment strength and the ultimate axial load of the wall $\left(M_{n}, P_{u, \max }\right)$. ACI 318-11 [27] defines the limit state of $c$ as:

$$
c \geq \frac{l_{w}}{600\left(\delta_{u} / h_{w}\right)} .
$$

Substituting the previous equations into Eq. (3) gives the closed-form solution for period estimation as:

$$
T_{c}=2 \pi \sqrt{\frac{h_{n}}{2 g}\left(\frac{R}{S_{a} \cdot I_{e}}\right) \cdot F_{u}},
$$

where:

$$
\begin{aligned}
F_{u} & =\int_{0}^{h_{n}}[u(x)]^{2} d x / \int_{0}^{h_{n}} x \cdot u(x) d x \\
& =\left(\frac{0.227 h_{n}}{0.905 h_{n}-0.637}\right) \cdot Z
\end{aligned}
$$

Parameter $Z$ denotes the top deformation of the wall based on geometric and mechanical parameters (elastic or plastic model) which can be obtained analytically for a SW. The ratios of $h_{w} / l_{w}=3.0, l_{w} / t_{w}=13.3$, and $h_{w} / t_{w}=40.0$ are fairly typical for US construction [26]. According to ACI 318-11 [27], $\alpha=0.5\left(l_{p}=0.5 l_{w}\right)$ and the neutral axis depth are considered to be 0.6 $\left(c=0.6 l_{w}\right)$. Since $\varepsilon_{s y}=0.002$ for the minimum wall reinforcement yield strain in ASTM A 615 [28], $Z=$ 0.0041 .

The fundamental period for buildings in Table 1 can be easily calculated from Eq. (13) using the design response spectrum in ASCE SEI/7-10 [4] to calculate

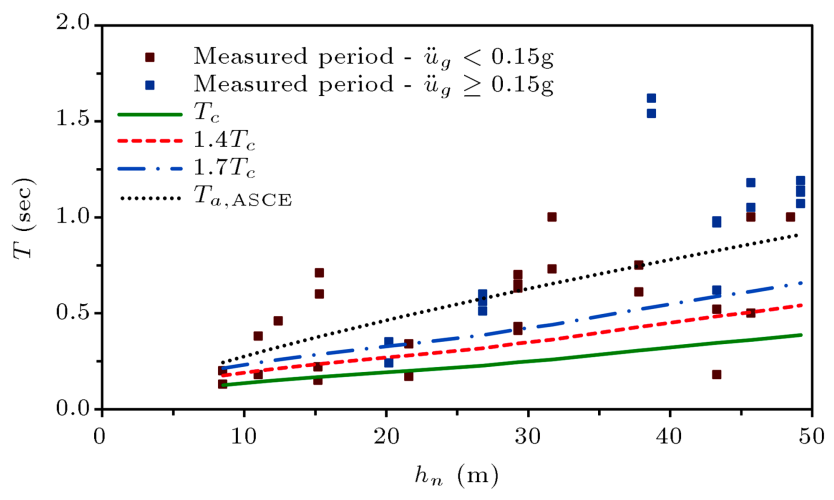

Figure 5. Comparison of $T_{c}, T_{a, \mathrm{ASCE}}$, and measured periods for concrete SW buildings.

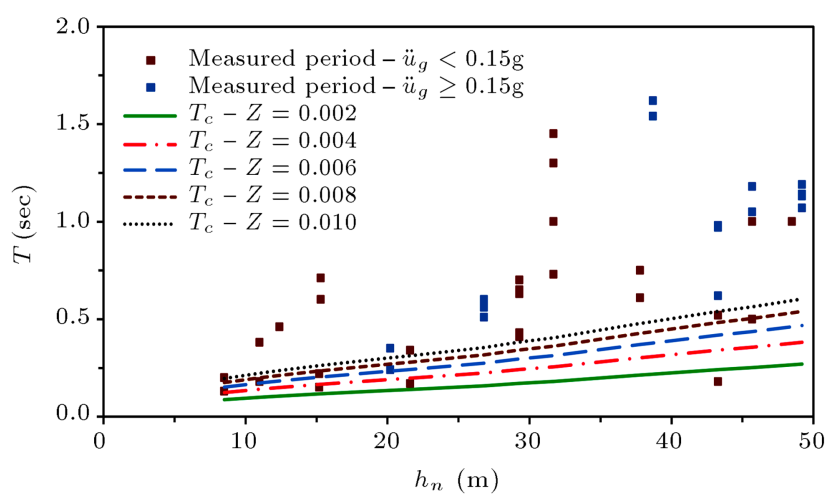

Figure 6. Comparison of $T_{c}$ with typical values of $Z$ and measured periods for concrete SW buildings.

$S_{a}$, where $R=5.5$ for reinforced concrete SWs, $I_{e}=1$, and $g=9.81 \mathrm{~m} / \mathrm{s}^{2}$.

Figure 5 compares the fundamental period of the buildings listed in Table 1 from $T_{c}$ and $T_{a, \mathrm{ASCE}}$ with measured periods. This figure shows that the periods of concrete SW buildings are strongly related to SW height and mechanical properties. The power expression of the closed-form equation is $T_{a}=0.028 h_{n}^{0.66}$ which adequately fits the lower bound of the measured period. Therefore, using factors 1.4 and 1.7 is more valid for the fundamental period.

Figure 6 compares $T_{c}$ with typical values of $Z$ and measured periods for concrete SW buildings. As seen, increasing $Z$ increases the period. Using the maximum value of 0.01 for wall deformation $(Z=0.01)$ (ACI 318-11 [27]), let $T_{c}$ estimate the fundamental period of the concrete SW building in regions with a different seismicity. For different values of $S_{a}$, factors 1.4 and 1.7 can be used according to the seismicity of a region for the valid lower bound of period estimations.

\section{Summary and conclusion}

The present study investigated the period formulas for concrete SW buildings in the current US codes. These formulas were compared with measured periods 
recorded from the responses of concrete SW buildings in earthquakes from the 1971 San Fernando earthquake to the 1994 Northridge earthquake for 16 buildings (27 records). The majority of measured periods were shorter than the periods obtained using the code formulas, which underestimated the seismic design loads in several cases. The results show that wall geometry and mechanical properties greatly affect the fundamental period of concrete SW buildings, where many measured periods for buildings of the same height were totally different. This indicates that using building height alone may not provide a valid period for these buildings.

Different periods were recorded during California earthquakes for several concrete SW buildings with similar geometry. If building height and SW width are only used, a comparison of measured periods and code formulas may show no advantage to the use of building height alone in a period formula. The results show that the wall deformation also played an important role in concrete SW building periods; hence, the use of the expressions $1.4 T_{a}$ and $1.7 T_{a}$ specified in building codes for mechanical methods can result in an appropriate period estimate.

A comparison of code periods and measured periods reveals that the code formulas for empirical concrete SW building periods in California (high seismicity region) were not adequate. A simple expression using Rayleigh's method was proposed for period estimation that fits the lower bound of the measured periods. The power equation of this expression was $T_{a}=0.028 h_{n}^{0.66}$ for California. For other seismic regions with different $S_{a}$ values, values greater than 1.4 can be provided using eigenvalue analysis.

\section{References}

1. Tremblay, R. "Fundamental periods of vibration of braced steel frames for seismic design", J. of Earth. Spect., 21(2), pp. 833-860 (2005).

2. ATC "Tentative provisions for the development of seismic regulations for buildings", ATC3-06, Аpp. Technol. Council, Palo Alto, CA (1978).

3. NRCC "National building code of Canada", 11th Ed., Canadian Commission on Building and Fire Codes, National Research Council of Canada, Ottawa, Ontario (1995).

4. ASCE "Minimum design loads for buildings and other structures", SEI/ASCE Standard No. 7-10, American Society of Civil Engineers, Reston, VA (2010).

5. Housner, G.W. and Brady, A.G. "Natural periods of vibration of buildings", J. Eng. Mech. Div., 89(4), pp. 31-65 (1963).

6. Cole, E.E. Tokas, C.V. and Meehan, J.F. "Analysis of recorded building data to verify or improve 1991 uniform building code (UBC) period of vibration formulas", Proc., SMIP92, Strong Motion Instrumentation
Program, Division of Mines and Geology. California Department of Conservation, Sacramento, CA (1992).

7. Li, Y. and Mau, S.T. "Learning from recorded earthquake motion of buildings", J. of Struc. Eng., 123(1), pp. 62-69 (1997).

8. Goel, R.K. and Chopra, A.K. "Period formulas for concrete shear wall buildings", J. of Struc. Eng., 124(4), pp. 426-433 (1988).

9. Lee, L.H., Chang, K.K. and Chun, Y.S. "Experimental formula for the fundamental period of RC buildings with shear-wall dominant systems", $J$. of the Struc. Des. of Tal. and Spe. Build., 9(4), pp. 295-307 (2000).

10. ICBO "Uniform building code", International Conference of Building Officials, Whittier, CA (1997).

11. Ghirb, F. and Mamedov, H. "Period formulas of shear wall buildings with flexible bases", J. of Earth. Eng. and Struc. Dyn., 33(3), pp. 295-314 (2004).

12. Kown, O.S. and Kim, E.S. "Evaluation of building period formulas for seismic design", J. of Earth. Eng. and Struc. Dyn., 39(14), pp. 1569-83 (2010).

13. Barghi, M. and Azadbakht, M. "Evaluating the effect of masonry infills on natural period of buildings with moment-resisting frame", J. of the Struc. Des. of Tal. and Spe. Build., 20(6), pp. 649-660 (2011).

14. Kusyilmaz, A. and Topkaya, C. "Fundamental periods of steel eccentrically braced frames", J. of the Struc. Des. of Tal. and Spe. Build., 24(2), pp. 123-14 (2014).

15. NEHRP, Recommended Provisions for the Development of Seismic Regulations for New Buildings, FEMA P-750, Building Seismic Safety Council, Washington, DC (2009).

16. ICC, 2012 International Building Code, International Code Council, Country Club Hills, IL (2011).

17. ECS Eurocode 8: Design of Structures for Earthquake Resistance, prEN1998-1, January 2003 Draft, European Committee for Standardization Brussels, Belgium (2003).

18. Hart, G.C., DiJulio, R.M. and Lew, M. "Torsional response of high-rise buildings", J. of Struc. Div., 101(2), pp. 397-416 (1975).

19. Hart, G.C. and Vasudevan, R. "Earthquake design of buildings: damping", J. of Struc. Div., 101(1), pp. 11-30 (1975).

20. McVerry, G.H. "Frequency domain identification of structural models from earthquake records", Report No. EERL 79-02, Earthquake Eng., Res. Lab, California Inst. of Technology, Pasadena, CA (1979).

21. Werner, S.D., Nisar, A. and Beck, J.L. "Assessment of UBC seismic design provisions using recorded building motion from the Morgan Hill, Mount Lewis, and Lorna Prieta earthquakes", 5 Dames and Moore, Oakland, CA (1992).

22. Gates, W.E., Hart, G.C., Gupta, S. and Srinivasan, M. "Evaluation of overturning forces of shear wall buildings", Proc., SMIP94, Strong Motion Instrumentation Program, Division of Mines and Geology, California Department of Conservation, Sacramento, CA (1994). 
23. Marshall, R.D., Phan, L.T. and Celebi, M. "Full-scale measurement of building response to ambient vibration and the Loma Prieta earthquake", Proc., 5th U.S. Nat. Con. of Earthquake Eng., II, Earthquake Eng., Res. Inst., Oakland, CA (1994).

24. Goel, R.K. and Chopra, A.K. "Evaluation of code formulas for fundamental period of buildings", $C D$ ROM Proc., 11th World Con. on Earthquake Eng., Paper No. 1127, Elsevier, Science Ltd, Oxford, UK (1996).

25. Goel, R.K. and Chopra, A.K. "Vibration properties of buildings determined from recorded earthquake motions", Report No. VCRIEERC-971J4. Earthquake Engineering Research Center, Richmond, CA (1997).

26. Wallace, J.W. "Behavior, design, and modeling of structural walls and coupling beams-lessons from recent laboratory tests and earthquakes", J. of Conc. Struc. and Mat., 6(1), pp. 3-18 (2012).

27. ACI, "Building code requirements for structural concrete (ACI 318-11) and commentary (ACI318R-11)", American Concrete Institute, Farmington Hills, Michigan (2011).

28. ASTM, "Standard specification for deformed and plain carbon-steel bars for concrete reinforcement", ASTM A 615/A615M-13, American Society for Testing and Materials, West Conshohocken, PA (2013).

\section{Biographies}

Alireza Badkoubeh completed his MSc degree in Structural Engineering in Kharazmi University and his undergraduate studies in Tafresh University. His research interests lie in the area of dynamic analysis of structures, seismic retrofitting of buildings and bridges, and improving seismic performance of structures using new innovative materials.

Ali Massumi received his $\mathrm{PhD}$ degree from Tarbiat Modares University in 2004. He is an Professor in Structural and Earthquake Engineering in Kharazmi University. He has been a visiting researcher in the University of Ottawa (Canada) in 2003, and a visiting scholar in the University of California, Los Angeles (UCLA) in 2013. His research activities mainly deal with structural and earthquake engineering including seismic behavior of RC structures, damage detection and assessment, seismic soil-structure interaction, progressive collapse, and retrofitting. He is the author or co-author of more than 10 books, technical regulations, and technical reports. He has published more than 100 papers in refereed journals and conferences. 